\title{
Production of some biologically active secondary metabolites from marine-derived fungus Varicosporina ramulosa
}

\author{
Atalla, M. Mabrouk., ${ }^{1}$ Zeinab, H. Kheiralla., ${ }^{2}$ Eman, R. Hamed., ${ }^{1}$ Amani, A. Youssry ${ }^{2}$ and Abeer, A. Abd El Aty ${ }^{1}$ \\ ${ }^{1}$ Chemistry of Natural and Microbial Products Dept. National Research Centre, Cairo, Egypt \\ ${ }^{2}$ Botany Dept. Faculty of Girls for Arts, Science and Education, Ain Shams University \\ E.mail: atallam@mailcity.com , erhamed@yahoo.com
}

\begin{abstract}
In a screening of fungal isolates associated with marine algae collected from Abou-keer, Alexanderia during the four seasons of 2004, to obtain new biologically active compounds. Varicosporina ramulosa isolate was identified and selected as a producer of 13 compounds. Out of 13 pure compounds produced, compounds 3 and 10 were considered as antibacterial and antifungal compounds, respectively as they were active against gram positive, gram negative bacteria and a fungus. Optimization of conditions (fermentation media, incubation period, temperature, initial $\mathrm{pH}$, aeration levels) which activate compounds 3 and 10 production were studied. Also the spectral properties (UV, MS, GC/MS, IR and ${ }^{1} \mathrm{H}-\mathrm{NMR}$ ) of the purified compounds were determined. Compound 3 suggested to be dibutyl phthalate and compound 10 may be ergosterol or one of its isomers. Biological evaluation of the two compounds towards 6 different types of tumor cell lines showed weak effect of compound 3 at different concentrations on the viable cell count of the different tumor cell lines. While compound 10 showed different activities against the viable cell count of the 6 different tumor cell lines. It kills $50 \%$ of the viable infected liver and lung cells at concentrations equal to $99.7 \mu \mathrm{g} / \mathrm{mL}, 74.9 \mu \mathrm{g} / \mathrm{mL}$, respectively. Compound 10 can be recommended as new anticancer compounds.
\end{abstract}

Keywords: Marine fungi, Cytotoxicity, Pharmaceuticals, Secondary metabolites, anticancer compounds, Varicosporina ramulosa.

\section{INTRODUCTION}

In recent years, chemical studies of culturable marine microorganisms have led to the discovery of numerous, structurally novel, biologically active secondary metabolites. Although most of these compounds were isolated from marine bacteria, a growing number of new structures have been reported from filamentous marine fungi.

Marine fungi proved to be a rich source of new biologically natural products (Cuomo et al., 1995; Farooq Biabani and Laatsch, 1998; Jensen and Fenical, 2000). Because of their particular living conditions, salinity, nutrition, high pressure, temperature variations, competition with bacteria, viruses and other fungi, they may have developed specific secondary metabolic pathways compared with terrestrial fungi (Liberra and Lindequist, 1995).

Recent investigations on marine filamentous fungi looking for biologically active secondary metabolites indicate the tremendous potential of them as a source of new medicines (Namikoshi et. al., 2002).

Belofsky et al. (1998) isolated four new sesquiterpenoid

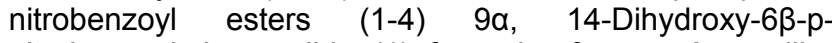
nitrobenzoyl-cinnamolide (1) from the fungus Aspergillus versicolor, which displayed significant cytotoxicity against
HCT-116 human colon carcinoma cells in vitro and exhibited moderately selective cytotoxicity towards a panel of renal tumor cell lines. In (1999) they isolated a new cyclic pentadepsipeptide, sansalvamide (1) from organic extracts of the mycelium of a marine fungus Fusarium. Sansalvamide exhibited selective in vitro cytotoxicity towards COLO 205 colon and SK-MEL-2melanoma cancer cell lines. In (2000) they isolated three new oxpincontaining natural products (1-3) and two new fumiquinazoline metabolites (4-5) from organic extracts of the culture broth and mycelia of a marine isolate of the genus Acremonium. Compound1 exhibited good antiinflammatory in a tropical RTX-induced mouse ear edema assay. Compounds 4 and 5 exhibited weak antifungal activity toward Candida albicans in broth microdilution assay.

Höller et al., (1999) recorded the production of five macrodiolides grahamimycin A1 (6), colletoketol (7), (6R, 11R, 12R, 14R)-colletodiol (8), 9, 10-dihydro-(6R, 11S, 12S, 14S)-colletodiol (9) and 9, 10-dihydro-(6R,11R, 12R, 14R)-colletodiol (10) together with ergosterol from marine fungus Varicosporina ramulosa (strain no. 195-31). Compound (9) and (10) being new fungal metabolites and showed antimicrobial activity against $E$. repens, compound

\section{Corresponding author}


7 also showed antifungal activities against $E$. repens and $U$. violacea,

Cueto et al., (2000) isolated N-Methylsansalvamide(1), a new cytotoxic cyclic depsipeptide from extracts of cultured marine fungus, strain CNL-619, identified as a member of the genus Fusarium. N-Methylsansalvamide exhibits weak in vitro cytotoxicity in the $\mathrm{NCl}$ human tumor cell line screen $\left(\mathrm{Gl}_{50} 8.3 \mu \mathrm{M}\right)$.

Chinworrungsee et al., (2001) recorded the production of three known compounds, 2-hexylidene-3-methylsuccinic acid (1), cytochalasin Q (2), and 5-carboxymellein (3), together with two new derivatives, 2-hexylidene-3methylsuccinic acid 4-methyl ester (4) and an ophiobolane sesterterpene named halorosellinic acid (5), from culture broth of the marine fungus Halorosellinia oceanica BCC5149. Compounds 1-3 exhibited moderate cytotoxicity against $\mathrm{KB}$ and $\mathrm{BC}-1$ cell lines with $\mathrm{IC}_{50}$ values of $1-13$ $\mu \mathrm{g} / \mathrm{ml}$, while compounds $2,3,5$, and 6 showed antimalarial activity with respective $\mathrm{IC}_{50}$ values of $17,4,13$, and 19 $\mu \mathrm{g} / \mathrm{ml}$. Halorosellinic acid (5) possessed only weak antimycobacterial activity with the minimum inhibitory concentration of $200 \mu \mathrm{g} / \mathrm{ml}$. Jadulco et al., (2001) reported the isolation of a new furan carboxylic acid, an acetyl derivative of sumikis acid from the marine fungus Cladosporium herbarum that was found to be active against Bacillus subtilis and S. aureus. Kuznetsova et al., (2001) identified the fusidic acid, a steroidal antibiotic from marine isolate of the fungus Stilbella aciculosa.

Bringmann et al., (2003) isolated two new products, evariquinone and isoemericellin from a strain of the fungus Emericella variecolor. Evariquinone showed antiproliferative activity towards KB and NCL-H460 cells at a concentration of $3.16 \mu \mathrm{g} / \mathrm{ml}$. Furthermore, the fungus was found to produce the known metabolites stromemycin, shamixanthone, and 7-hydroxyemodin.

Wei et al., (2004) attained two new sesterterpenes, 6epi-ophiobolin $\mathrm{G}$ and 6-epi-ophiobolin $\mathrm{N}$, and six known ophiobolins from the extracts of the fungus Emericella variecolor GF10. Ophiobolin K showed cytotoxic activity against various tumor cell lines, including adriamycinresistant mouse leukemia cells (P388), with $\mathrm{IC}_{50}$ of 0.27 $0.65 \mu \mathrm{M}$. In (2005) he attained shimalactone A (1), a novel polyketide having bicycle [4.2.0] octadine and oxabicyclo [2.2.1] heptane units. From the same marine fungus Emericella variecolor GF10, Shimalactone A (1) induced neuritogenesis at $10 \mu \mathrm{g} / \mathrm{mL}$ against neuroblastoma Neuro $2 \mathrm{~A}$ cells.

Lin et al., (2005) isolated new compound (1), named diaporthelactone, together with two known compounds (2 and 3) from the culture of the marine fungus Diaporthe sp., Compound (1) showed ctotoxic activity against KB and Raji cell lines (IC50 6.25 and $5.51 \mu \mathrm{g} / \mathrm{mL}$, respectively ). The two known compounds also were demonstrated to exhibit ctotoxic activities for the first time. All three compounds were assessed for antimicrobial activity. Tsukamoto et al.,
(2005) extracted a new ubiquitin-activating enzyme (E1) inhibitor, himeic acid $A$, from a culture of marine-derived fungus, Aspergillus sp. but in (2006) they isolated hexylitaconic acid, a new inhibitor of p53-HDM2 interaction, from a culture of marine derived fungus, Arthrinium $s p$.

Sun et al., (2006) reported the production of a new cyclotetrapeptide, trichoderide $A$, from the marine fungus Trichoderma reesei. Which showed moderate cytotoxicity against human A375-S2 melanoma cell line. Xu et al., (2006) isolated three new trichothecenes, named 12hydroxyroridin $E(1)$, roridin $Q(2)$, and 2,3 deoxyroritoxin $D$ (3) from the marine-derived fungus Myrothecium roridum TUF 98F42, and a new macrocyclic trichothecene, named roridin $\mathrm{R}$ (4) from Myrothecium sp. TUF 02F6 together with roridins $A$ and $H$ and isororidin $E$. The $I C 50$ values of compounds 1,2 , and 4 against the murine leukemia cell line $\mathrm{L} 1210$ were $0.19,31.2$, and $0.45 \mathrm{uM}$, respectively. Compound 3 showed antiyeast activity to Saccharomyces cerevisiae at $1 \mathrm{ug} / \mathrm{disc}$.

$\mathrm{Gu}$ et al., (2007) isolated two new cyclic peptides, microsporins $A$ and $B$ ( 7 and 8 ) from culture extracts of the marine-derived fungus Microsporum cf. gypseum. The microsporins $A$ and $B$ were the first cyclic tetrapeptide histone deacetylase inhibitors with significant cancer cell cytotoxicities. Microsporin A (7) showed in vitro cytotoxicity against human colon adenocarcinoma HCT-116 (IC50 0.6 $\mathrm{mg} / \mathrm{mL}$ ) and a mean IC50 value of $2.7 \mathrm{mM}$ in the National Cancer Institute's diverse 60-cell line panel. Microsporin B showed reduced in vitro cytotoxicity against HCT-116 (IC50 $8.5 \mathrm{mg} / \mathrm{mL})$.

\section{MATERIALS AND METHODS}

\section{Fermentatiom media}

Five liquid fermentation media were used in this study. All the ingredients of these media were dissolved in $800 \mathrm{~mL}$ sterile sea water and $200 \mathrm{~mL}$ distilled water, $\mathrm{pH}$ was adjusted at 6.2 and sterilized at $121^{\circ} \mathrm{C}$ for $15 \mathrm{~min}$.

Biomalt broth $(B / O)$ in $\mathrm{g} / \mathrm{L}$.

Biomalt $20 \mathrm{~g}$. (Sheng Wang et al., 1998).

Malt extract broth (MS) in $\mathrm{g} / \mathrm{L}$.

Malt extract $30 \mathrm{~g}$, peptone $3 \mathrm{~g}$.

Potato carrot broth (KM) in $\mathrm{g} / \mathrm{L}$.

$20 \mathrm{~g}$ of potatoes were sliced and cooked for $30 \mathrm{~min}$ in a suitable volume of distilled water, the left to stand, squeezed through muslin layers and the extracted decoction was collected. The same procedure was adopted for carrot. Both decoctions were pooled, mixed, and volume was adjusted to 1 liter. $\mathrm{pH}$ of the medium was adjusted to the desired number using $0.1 \mathrm{~N} \mathrm{HCL}$ or $0.1 \mathrm{~N} \mathrm{NaOH}$. The medium was distributed in $250 \mathrm{~mL}$ conical flasks each 
containing $50 \mathrm{ml}$ medium. The flasks were sterilized for 15 $\min$ at $15 \mathrm{lbs}$.

\section{Cellulose broth $(g / L)$}

Cellulose powder $10 \mathrm{~g}$, yeast extract $1.0 \mathrm{~g}$.

Glucose peptone yeast extract broth (GPY) in $\mathrm{g} / \mathrm{L}$

Glucose. $\mathrm{H}_{2} \mathrm{O} 1.0 \mathrm{~g}$, peptone $0.5 \mathrm{~g}$, yeast extract $0.1 \mathrm{~g}$. (Shigemori et al., 1999; Iwamoto et al., 2001).

\section{Procedure of fermentation}

Biomalt medium (BIO) was used as liquid fermentation medium for obtaining secondary metabolites (Höller, 1999). $250 \mathrm{ml}$ conical flasks were used each containing $50 \mathrm{ml}$ of sterile medium. Each flask was inoculated with 2 discs, 10 $\mathrm{mm}$. diameter, from 7 days old cultures formerly inoculated with $1 \mathrm{ml}$ spore suspension $\left(10^{4}\right.$ spore $\left./ \mathrm{mL}\right)$ of the solid biomalt agar (BIO) medium. Inoculated flasks were incubated on a rotary shaker at $65 \mathrm{rpm}$, for 14 days at 22 ${ }^{\circ} \mathrm{C}$.

Extract preparation (Belofsky et al., 1998; Höller, 1999 and Lin et al., 2000).

At the end of each growth period, inoculated flasks were collected and centrifugated. Both mycelia and filtrate were separately subjected to solvent extraction as follows:-

\section{Extraction of the mycelia}

The fresh mycelium of each fungus was washed three times with sterile distilled water to remove adherent filtrate, and then plotted between folds of sterilized filter paper no 1. The plotted mycelium was crushed by silica gel 60 in mortar, extracted by ethyl acetate to obtain intracellular metabolites. Both crushing and extraction were repeated three times, left in separating funnel for $15 \mathrm{~min}$ to precipitate. The crude ethyl acetate was collected.

\section{Extraction of the filtrate}

The filtrate of each fungus was extracted several times with ethyl acetate $(v / v)$ in a separating funnel.

The combined ethyl acetate extracts from both mycelia and filtrate were evaporated under vacuum at $50{ }^{\circ} \mathrm{C}$ till dryness. The obtained solid material was dissolved in ethyl acetate to form the crude extract.

\section{Determination and purification of the biologically active compounds}

Active compounds were determined by thin layer chromatography (TLC). Crude extracts in ethyl acetate were spotted $2 \mathrm{~cm}$ from the bottom of a precoated aluminum sheet of silica gel $60 \mathrm{~F}_{254}$ (Merk). Glass jars were saturated overnight by the solvent system dicholoromethane: methanol (95: 5) ( $v / v)$. The silica gel sheet allowed to dry and then developed in an ascending order for few hours until solvent front about $16 \mathrm{~cm}$ length.

Produced spots were located by their fluorescence on chromatograms under short and long wave UV light (254 and $366 \mathrm{~nm}$ respectively). The $R_{\mathrm{f}}$ values were determined and available pure compounds were used to prepare standard curves and also analyzed by using UV spectrophotometer.

\section{Bioassay of the active compounds}

The pure compounds produced were tested for anti microbial activity against a gram negative bacterium (Eschericia coli), a gram positive bacterium (Bacillus subtilis), Candida albicans and Fusarium solani.

Antibiotic assay by filter paper disc method (Ely et al., 2004; Petit et al., 2004) was carried out by impregnation of the compounds on filter paper discs of the same diameter $(5 \mathrm{~mm})$.

Petri dishes containing $30 \mathrm{~mL}$ of growth medium (nutrient agar for bacteria and Dox media for fungi and yeast) were seeded with the test organism. Discs containing the compounds were placed on the surface of the medium at suitably spaced apart. Inhibition zones around each disc were measured in $\mathrm{mm}$. after incubation at $35^{\circ} \mathrm{C}$ for $24-48 \mathrm{~h}$. for bacteria and yeast, and at $28-30{ }^{\circ} \mathrm{C}$ for 3-5 days for fungi.

\section{Physical properties of biologically active compounds}

The pure compounds were subjected to the following analysis:

High resolution mass spectra (MS) and (GC/MS) were obtained on a finnigan Mat SSQ-7000 spectrometery.

The infra red spectra (IR) were obtained on the Fourier Transform infra red spectrometer (Nicolet, model 670, USA) using pellet of $\mathrm{KBr}$.

Nuclear Magnetic Resonance ( $\left.{ }^{1} \mathrm{H}-\mathrm{NMR}\right)$ was measured on Jeol ECA 500. The compound was dissolved in dimethyl- $d_{6}$-sulphoxide (DMSO, $99.5 \%$ deuterium).

\section{Biological evaluation of active compounds}

Natural products may serve as lead as sources for new pharmaceuticals. Thus, the obtained pure compounds were evaluated in a diverse set of bio-assay. This include specific assays, e.g. for cytotoxicity performed in cooperation with other research groups in Pharmacology unit, National Cancer Institute, Cairo University.

The biologically active compounds were tested for any cytotoxic activity against the tumor cell lines i.e., Brain tumor cell line (U251), Liver carcinoma cell line (HEPG2), 
Breast carcinoma cell line (MCF7), Lung carcinoma cell line (H460), Cervix carcinoma cell line (HELA) and Colon carcinoma cell line (HCT116) at drug concentration between $(0-100 \mathrm{ug} / \mathrm{ml})$ using the SRB assay.

\section{Measurement of potential cytotoxicity by SRB assay}

Potential cytotoxicity of the compound(s) was tested using the method of SKehan et al. (1990). Cells were plated in 96-multiwell plate $\left(10^{4}\right.$ cells/ well) for $24 \mathrm{~h}$ before treatment with the compound (s) to allow attachment of cells to the wall of the plate. Different concentrations of the compound under test $(0,10,25,50$ and $100 \mathrm{ug} / \mathrm{mL})$ were added to the cell monolayer. Triplicate wells were prepared for each individual dose (concentration). Monolayer cells were incubated with the compound (s) for $48 \mathrm{~h}$ at $37^{\circ} \mathrm{C}$ and in atmosphere of $5 \% \mathrm{CO}_{2}$. After incubation for $48 \mathrm{~h}$, cells were fixed, washed and stained with sulforhodamine B stain. Excess stain was washed with acetic acid and attached stain was recovered with Tris EDTA buffer. Color intensity was measured in an ELISA reader. The relation between surviving cells and drug conc. is plotted to get the survival curve of each tumor cell line under the effect of the specified compound.

\section{RESULTS AND DISCUSSION}

\section{Separation and antimicrobial investigation of the extract}

The crude extract of the marine fungal genera $V$. ramulosa was spotted on precoated silica gel sheets $\mathrm{F}_{254}$ and allowed to dry, plates were developed in the following solvent system: Dichloromethane: Methanol (95:5 v/v).

Antimicrobial investigations were done on the separated compounds as in Table 1. The results showed that the solvent system dichloromethane: methanol $(95: 5 \mathrm{v} / \mathrm{v})$ separated a large number of compounds (13) present in base line, from $V$. ramulosa. The compounds were separated from each other and the most active compounds were 3 and 10 . Compound 3 had broad spectra against bacteria, yeast, and fungus as antibacterial and antifungal compound. However, compound 10 showed activity against both gram positive (B. subtillis), gram negative ( $E$. coli) and yeast (C. albicans).

Höller et. al., (1999) recorded the production of five macrodiolides grahamimycin A1 (6), colletoketol (7), (6R, $11 \mathrm{R}, 12 \mathrm{R}, 14 \mathrm{R})$-colletodiol (8), 9, 10-dihydro-(6R, 11S, 12S, 14S)-colletodiol (9) and 9, 10-dihydro-(6R,11R, 12R, $14 \mathrm{R})$-colletodiol (10) together with ergosterol from marine fungus $V$. ramulosa (strain no. 195-31). Compound (9) and (10) being new fungal metabolites and showed antimicrobial activity against $E$. repens, compound 7 also showed antifungal activities against $E$. repens and $U$. violace.

From these results it was recommended that the solvent system dichloromethane: methanol $(95: 5 \mathrm{v} / \mathrm{v})$ was the most promising one for active compounds separation.

\section{Physiological factors affecting compounds 3 and 10 production by Varicosporina ramulosa}

The aim of these studies was to optimize the physiological factors enhancing maximum production of active compounds.

V. ramulosa produced 13 different compounds, extracted from culture filtrate with ethyl acetate and purified by TLC using the solvent system dichloromethane: methanol (95:5; v/v). Compounds 3 and 10 were the most active against gram positive, gram negative bacteria and fungus. They considered as anti-bacterial and anti-fungal compounds (broad spectrum).

Survey of medium favoring compounds 3 and 10 production

The aim of this experiment was to select the most favorable medium for compounds 3 and 10 production. The fungal isolate was inoculated in 5 different media i.e., BIO, MS, $\mathrm{KM}$, Cellulose broth and GPY. The same procedure as mentioned in materials and methods section was adopted.

The results in Figure 1 showed that $V$. ramulosa produced variable amounts of compounds 3 and 10 on all the different media used. Data also revealed that MS medium was the most favorable for compounds 3 and 10 production $(7.598 \mathrm{mg} / \mathrm{L})$ and $(17.298 \mathrm{mg} / \mathrm{L})$ respectively, while KM medium was the lowest media for compound 3 productions $(2.147 \mathrm{mg} / \mathrm{L})$ also cellulose broth medium for compound10 production (1.603 $\mathrm{mg} / \mathrm{L})$.

From the aforementioned results, it was clear that the marine fungus $V$. ramulosa showed different activities for compounds 3 and 10 production according to the medium composition.

These results agreed with what obtained by Höller et. al., (1999) from the fungus $V$. ramulosa (strain no. 195-31) when cultured on sea water and malt extract-containing medium for the production of five macrodiolides grahamimycin 6-10.

Effect of incubation period on compounds 3 and 10 production

The main goal of this experiment was to determine the optimum incubation period for $V$. ramulosa active compounds production. The fungus was grown in biomalt 
medium (BIO), at pH 6.2. Inoculated flasks were incubated at $24{ }^{\circ} \mathrm{C}$ on an incubator shaker (65 rpm) for 16 days. The compounds production was determined each two days.

The results in Figure 2 showed that there was a consistent relation between incubation period and compounds 3 and 10 production. Compound 3 increased gradually at prolonged periods of incubation until reached the maximum $(5.397 \mathrm{mg} / \mathrm{L})$ after 8 days, then decreased. Compound 10 reached the maximum $(7.163 \mathrm{mg} / \mathrm{L})$ after 10 days and then decreased.
The obtained results are in agreement with those of Kuznetsova et al., (1998) who incubated flasks of marine Cladosporium sphaerospermum for 8 days for sterols production. But lined with those of Sabu et al. (2000) who incubated flasks of marine Beauveria sp. for 5 days for Lglutaminase production. Compound 10 increased gradually by increasing incubation period until reached the maximum (7.163 mg/L) after 10 days, then decreased.

Table 1: Antibacterial and antifungal activities of the separated compounds produced by $V$. ramulosa by using the solvent system dichloromethane: methanol $(95: 5 \mathrm{v} / \mathrm{v})$.

\begin{tabular}{lllll}
\hline \multirow{2}{*}{ Separated compounds } & \multicolumn{4}{l}{ Diameter of inhibition zone in $(\mathrm{mm})$} \\
\cline { 2 - 5 } & E. coli & B. subtillis & C. albicans & F. solani \\
\hline V. ramulosa & 11 & 14 & 13 & 0 \\
1 & 0 & 0 & 8 & 0 \\
2 & $11^{*}$ & $12^{*}$ & $14^{*}$ & $15^{*}$ \\
3 & 0 & 0 & 0 & 0 \\
4 & 0 & 0 & 0 & 10 \\
5 & 0 & 0 & 0 & 8 \\
6 & 9 & 7 & 0 & 8 \\
7 & 9 & 9 & 7 & 8 \\
8 & 9 & 9 & 7 & 9 \\
9 & $8^{*}$ & $12^{*}$ & $11^{*}$ & 0 \\
10 & $9^{*}$ & 0 & 0 & 0 \\
11 & $9^{*}$ & 8 & 9 & 9 \\
12 & & 8 & & \\
& $9^{*}$ & 8 & 0 & 9 \\
\hline
\end{tabular}

\section{Effect of temperature on compounds 3 and 10 production}

This experiment was designed to determine the optimum temperature for fungal growth to produce high quantity of compounds. BIO medium was used for growing the fungus isolate and incubated on an incubator shaker at different degrees of temperature $\left(22,24,26,28,30\right.$ and $\left.32{ }^{\circ} \mathrm{C}\right)$. The aforementioned culture conditions were adopted.

Results showed that compound 3 production increased as incubation temperature increased until reached maximum $(6.225 \mathrm{mg} / \mathrm{L})$ at $24^{\circ} \mathrm{C}$ and then declined Figure 3. Compound 10 recorded maximum production (5.995 $\mathrm{mg} / \mathrm{L})$ at $26^{\circ} \mathrm{C}$.

These results agreed with Raghukumer et al., (1999) who incubated culture flasks of a marine Flavodon flavus for lignin-modifying enzymes (LMEs) production at room temperature (25 to $27^{\circ} \mathrm{C}$ ), while marine Cladosporium sphaerospermum produced sterols in fermentation medium at temperature of $22{ }^{\circ} \mathrm{C}$ (Kuznetsova et al., 1998).

Effect of different initial $\mathrm{pH}$ values on compounds 3 and 10 productions

This has been done to determine the optimum $\mathrm{pH}$-values of fermentation medium suitable for biologically active compounds production. The initial $\mathrm{pH}$ of $\mathrm{BIO}$ medium was adjusted at $3,3.5,4,4.5,5,5.5,6,6.2,6.5,7,7.5$ and 8.0. The inoculum size and incubation conditions were as described in the previous experiments.

The results illustrated in Figure 4 showed that the initial $\mathrm{pH}$ of the medium suitable to enhance growth of $\mathrm{V}$. ramulosa to produce high quantity of compound 3 (5.833 $\mathrm{mg} / \mathrm{L})$ and compound 10 (15.751 $\mathrm{mg} / \mathrm{L})$ was $\mathrm{pH} 6$, but deviation to more or less $\mathrm{pH}$ caused decline in compounds production. 
These results lined with those of Keerthi et. al., (1999) who adjusted the $\mathrm{pH}$ of fermentation medium at 8.0 , to produce L- glutaminase by Beauveria bassiana BTMF S10.

\section{Effect of aeration levels on compounds 3 and 10 production}

It was economically important to examine the role of aeration levels on compounds 3 and 10 production in biomalt medium (BIO). In order to maintain different levels of aeration, Erlenmeyer flasks $(250 \mathrm{~mL})$ were used for fungal growth and incubated on an incubator shaker at different rpm $(0,65,100,150,180,200$, and 220$)$.

After incubation period of 14 days at $24{ }^{\circ} \mathrm{C}$ and $\mathrm{pH}$ 6.2, production of compounds 3 and 10 by $V$. ramulosa were illustrated in Figure 5. It was observed that increasing aeration levels activate compound 10 production till reached maximum $(17.002 \mathrm{mg} / \mathrm{L})$ at $150 \mathrm{rpm}$, but reached maximum at $65 \mathrm{rpm}$ for compound $3(2.734 \mathrm{mg} / \mathrm{L})$.

The results for compound 10 agreed with those mentioned by Suresh and Chandrasekaran (1999), who incubated flasks of Beauveria bassiana on a rotary shaker at $150 \mathrm{rpm}$ for chitinase production.

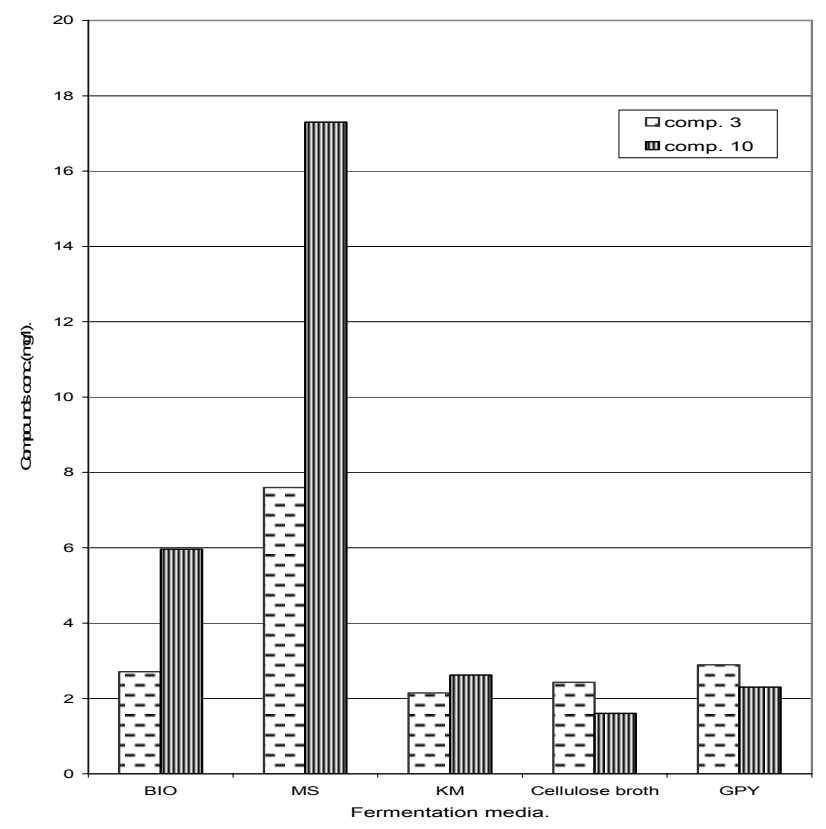

Figure 1: Effect of different fermentation media on compounds 3 and 10 production

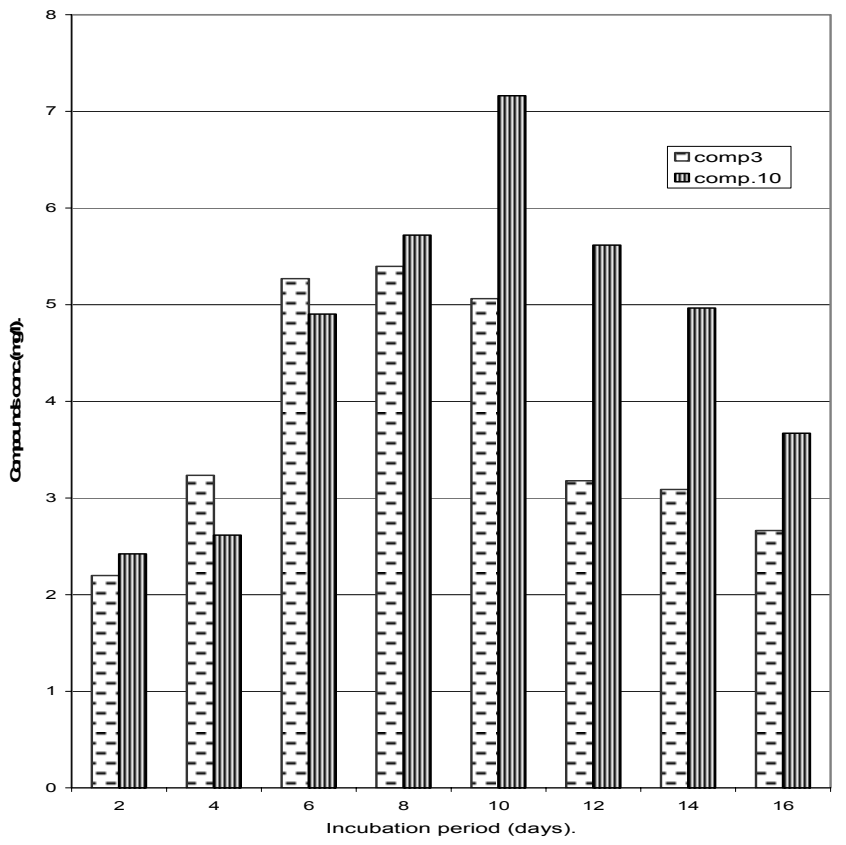

Figure 2: Effect of incubation period on compounds 3 and 10 production

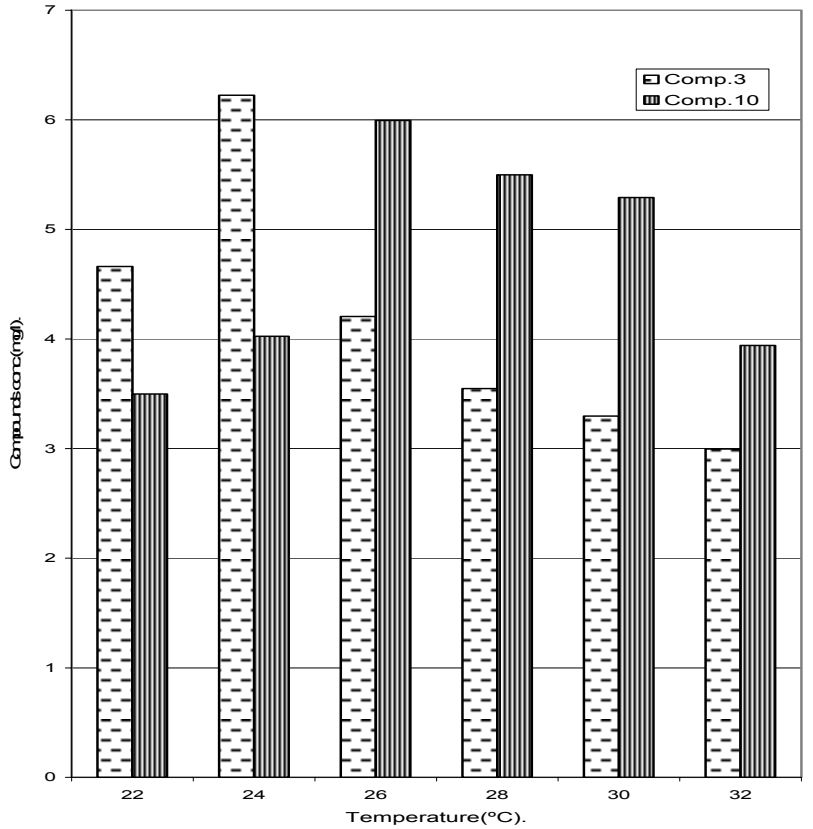

Figure 3: Effect of temperature on compounds 3 and 10 production 


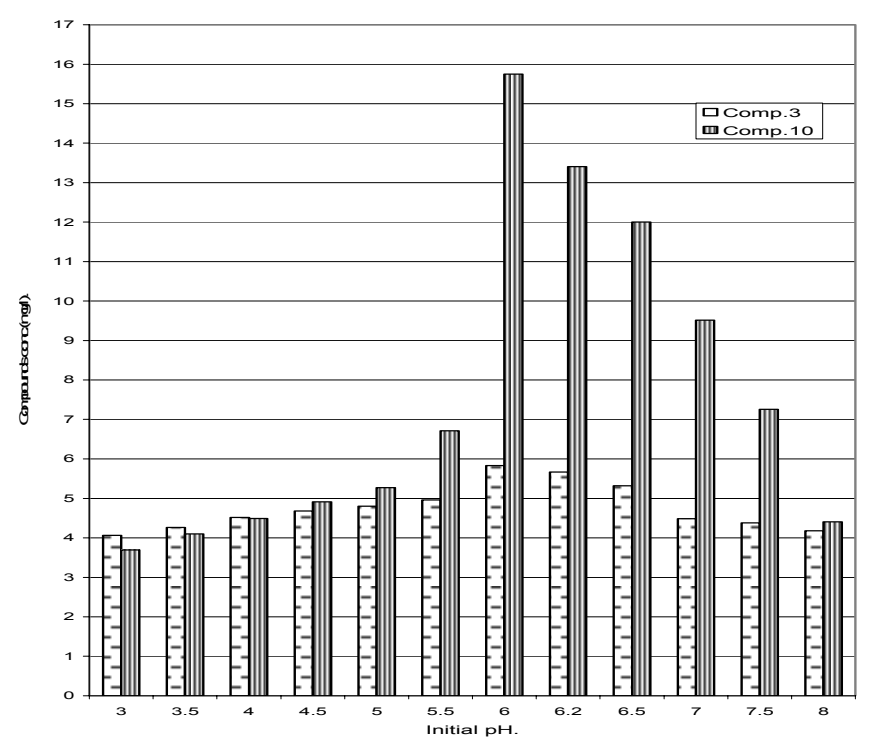

Figure 4: Effect of different initial $\mathrm{pH}$-values on compounds 3 and10 production

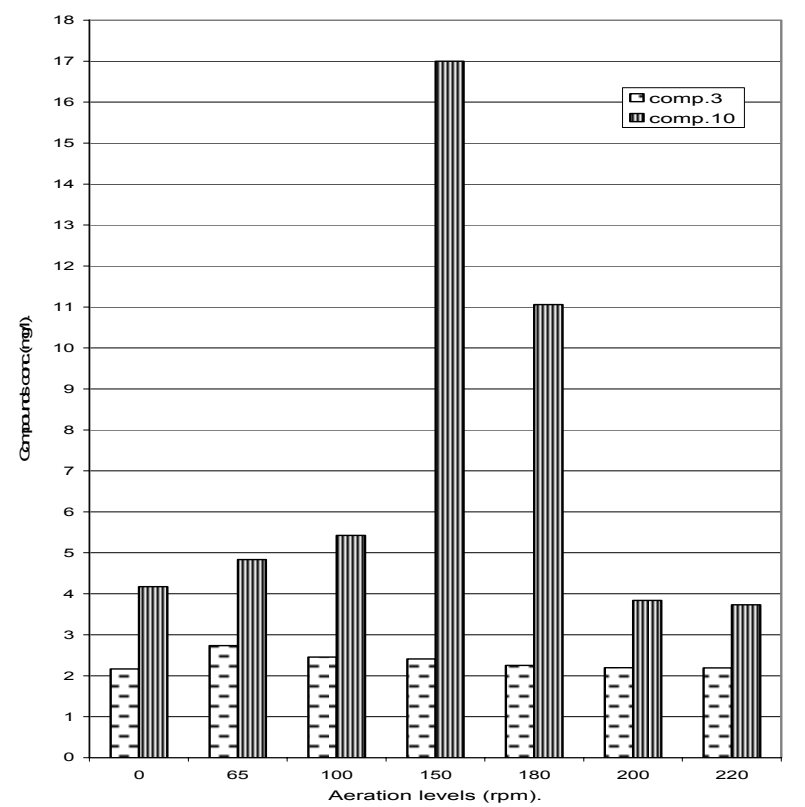

Figure 5: Effect of different aeration levels on compounds 3 and 10 production
Structural elucidation of the most active compounds (Budzikiewicz et al., 1964; Williams and Fleming, 1980).

\section{Identification of compound 3}

The ultraviolet absorption spectrum of compound 3 , showed absorption band at $\lambda$ max. (Methanol) $260 \mathrm{~nm}$.

The infrared spectrum of compound 3 , showed characteristic absorption bands at $3436 \mathrm{~cm}^{-1}(\mathrm{OH}), 2926$ $\mathrm{cm}^{-1}\left(\mathrm{C}-\mathrm{H}\right.$, aliphatic), $1728 \mathrm{~cm}^{-1}(\mathrm{C}=\mathrm{O}$, aryl carbonyl of ester), $1570 \mathrm{~cm}^{-1}$ and $1420 \mathrm{~cm}^{-1}$ (COO , carboxylate ion).

Note: usually water in trace amounts (Water of crystallisation), in $\mathrm{KBr}$ discs showed a broad band in the range $3100-3600 \mathrm{~cm}^{-1}$.

The ${ }^{1} \mathrm{H}$ NMR spectrum of compound 3 (DMSO), showed signals at $\delta 0.83\left(3 \mathrm{H}, \mathrm{t}, \mathrm{CH}_{3}\right)$ and $1.0\left(3 \mathrm{H}, \mathrm{t}, \mathrm{CH}_{3}\right)$ at $\delta 1.25-$ $2.48\left(12 \mathrm{H}, \mathrm{m}, 6-\mathrm{CH}_{2}\right)$ and $6.63-7.26(4 \mathrm{H}, \mathrm{m}$, aromatic protons).

The mass spectrum (rel. int. \%) of compound 3, showed the molecular ion at $\mathrm{m} / \mathrm{z} 279\left(\mathrm{M}^{+}+1\right)(13)$, and other fragments at 167 (40), 149 (100), 132 (5), 113 (30), 104 (10), 83 (28), 71 (34) and 55 (55). The fragments at $\mathrm{m} / \mathrm{z}$ 149, 167 and 279 due to phthalic acid derivatives (dialkyl phthalate) and its molecular ion at $\mathrm{m} / \mathrm{z} 278$ corresponding to molecular formula $\mathrm{C}_{16} \mathrm{H}_{22} \mathrm{O}_{4}$.

The obtained data, UV, IR, ${ }^{1} \mathrm{H}$ NMR and MS suggested that the isolated compound may be dibutyl phthalate Figure 6 and Table 2.

\section{Identification of compound 10}

The ultraviolet absorption spectrum of compound 10, showed absorption band at $\lambda$ max. (Methanol) $274 \mathrm{~nm}$.

The infrared spectrum of compound 10, showed characteristic absorption bands at $3468 \mathrm{~cm}^{-1}(\mathrm{OH}), 2990$ $\mathrm{cm}^{-1}\left(\mathrm{C}-\mathrm{H}\right.$, aliphatic), $1417 \mathrm{~cm}^{-1}(\mathrm{CH}=\mathrm{CH})$ and $1023 \mathrm{~cm}^{-1}($ $\mathrm{C}-\mathrm{OH}$, alcoholic).

The ${ }^{1} \mathrm{H}$ NMR spectrum of compound 10 (DMSO), showed signals at $\delta 0.79\left(3 \mathrm{H}, \mathrm{CH}_{3}\right), 0.84\left(3 \mathrm{H}, \mathrm{CH}_{3}\right), 0.86$ $(3 \mathrm{H}, \mathrm{CH} 3), 0.87\left(3 \mathrm{H}, \mathrm{CH}_{3}\right), 0.88\left(3 \mathrm{H}, \mathrm{CH}_{3}\right)$ and $1.06(3 \mathrm{H}$, $\left.\mathrm{CH}_{3}\right)$. Also, signals at 1.22-2.26 $(19 \mathrm{H}, \mathrm{m}), 2.49-2.67(2 \mathrm{H}$, $\mathrm{m}), 3.49-4.35(5 \mathrm{H}, \mathrm{m})$ and at $\delta 8.5(1 \mathrm{H}, \mathrm{OH})$.

The mass spectrum (rel. int. \%) of compound 10, showed $\mathrm{M}^{+}$at $\mathrm{m} / \mathrm{z} 396$ (5), corresponding to molecular formula $\mathrm{C}_{28} \mathrm{H}_{44} \mathrm{O}$. It loses $\mathrm{CH}_{3}+\mathrm{H}_{2} \mathrm{O}$ at $\delta 363$ (3) $\left[\mathrm{M}^{+}\right.$$\left.\left(\mathrm{CH}_{3}+\mathrm{H}_{2} \mathrm{O}\right)\right]$. Fragment at $278(7.5)\left(\mathrm{M}^{+}-\mathrm{C}_{9} \mathrm{H}_{17}\right)$, and other fragments at m/z 253 (3), 211 (4), 185 (5), 167 (32), 149 (77.5), 133 (18), 109 (23), 95 (30), 81 (47), 69 (95) and 53 (100).

The obtained data, UV, IR, ${ }^{1} \mathrm{H}$ NMR and MS suggested that the isolated compound may be ergosterol or one of its isomers Figure 6 and Table 2. 


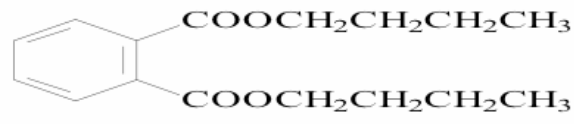

n-Dibutylphthalate

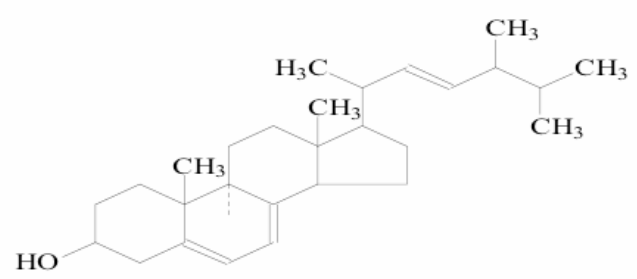

Ergosta-5,7,22-trien-3ß-ol (Ergosterol)

Figure 6: Structure of compound 3 and 10 produced by $V$. ramulosa

\section{Biological evaluation of active compounds}

The obtained pure compounds were evaluated for potential cytotoxicity, against 6 tumor cell lines i.e. brain tumor cell line (U251), liver carcinoma cell line (HEPG2), breast carcinoma cell line (MCF7), lung carcinoma cell line $(\mathrm{H} 460)$, cervix carcinoma cell line (HELA) and colon carcinoma cell line (HCT116).

Each cell line was treated with serial concentrations of $10,25,50$ and $100 \mathrm{ug} / \mathrm{mL}$ of each compound, and incubated at $37{ }^{\circ} \mathrm{C}$ in $5 \% \mathrm{CO}_{2}$. Viable cells were counted after $48 \mathrm{~h}$ from incubation.

Compound 3 obtained from the fungus $V$. ramulosa was tested for any cytotoxic activity against the 6 tumor cell lines

From the results illustrated in Figure 7 it was clear that, compound 3 has weak effect on brain, liver, lung, cervix and colon viable infected cells and the concentration of $100 \mu \mathrm{g} / \mathrm{mL}$ kills nearly $20 \%$ of the viable cells.

Also it was appeared that the maximum concentration $100 \mu \mathrm{g} / \mathrm{mzl}$ of compound 3 kills only $10 \%$ of the viable breast infected cells.

Compound 10 obtained from the fungus $V$. ramulosa was tested for any cytotoxic activity against the 6 tumor cell lines

From the results illustrated in Figure 8, it was clear that different concentrations of compound 10 have different activities against the viable cells of the 6 different tumor cell lines, where the maximum concentration $100 \mu \mathrm{g} / \mathrm{mL}$ has weak effect on the viable cells of breast and colon carcinoma cell lines $20 \%$, it kills about $30 \%$ of the viable cervix infected cells. Also, the number of viable infected brain cells decreases gradually by increasing compound 10 concentration until reached the maximum concentration used $100 \mu \mathrm{g} / \mathrm{mL}$, which kills about $40 \%$ of the viable cells, so it is considered as a moderate active compound. Increasing compound 10 concentrations was in favor of more death of viable infected liver and lung cells and reached maximum at the concentration $100 \mu \mathrm{g} / \mathrm{mL}$ which kills approximately $50 \%$ of the viable cells which was in a range equal to $50-100 \mu \mathrm{g} / \mathrm{mL}$. $\quad\left(\mathrm{IC}_{50}=99.7 \mu \mathrm{g} / \mathrm{mL}\right)$, $\left(\mathrm{IC}_{50}=74.9 \mu \mathrm{g} / \mathrm{mL}\right)$, respectively.

The compound produced can be recommended as new anticancer compound. The weak effect of compound 10 on colon carcinoma cell line agree with (Abdel-Wahab et al., 2007) who found that, the Massarina CNT-016 metabolites (1-4) showed weak activity against the human colon carcinoma cell line, HCT-116.

Mcdonald et al., (1999) extracted spiroxins (1-5), DNA cleaving antitumor antibiotics from culture of a marinederived fungus (strain LL-37H248). And also from the fungus Beauveria bassiana BTMF S10, Keerthi et al., (1999) stated the production of extracellular L-glutaminase by alkalophilic L-glutaminase which received significant attention recently owing to its potential applications in medicine as an anticancer agent and in food industries.

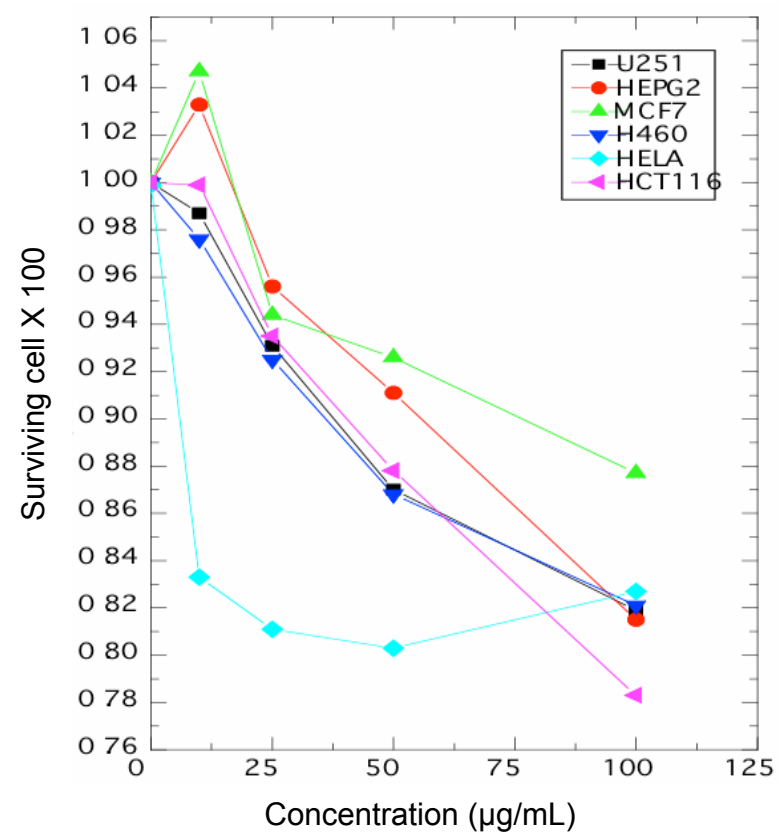

Figure 7: Effect of different concentrations of compound 3 on the viability of 6 different types of tumor cell lines 
Mal. J. Microbiol. Vol 4(1) 2008, pp. 14-24

Table 2: Physical characterization of compounds 3 and 10 produced by Varicosporina ramulosa

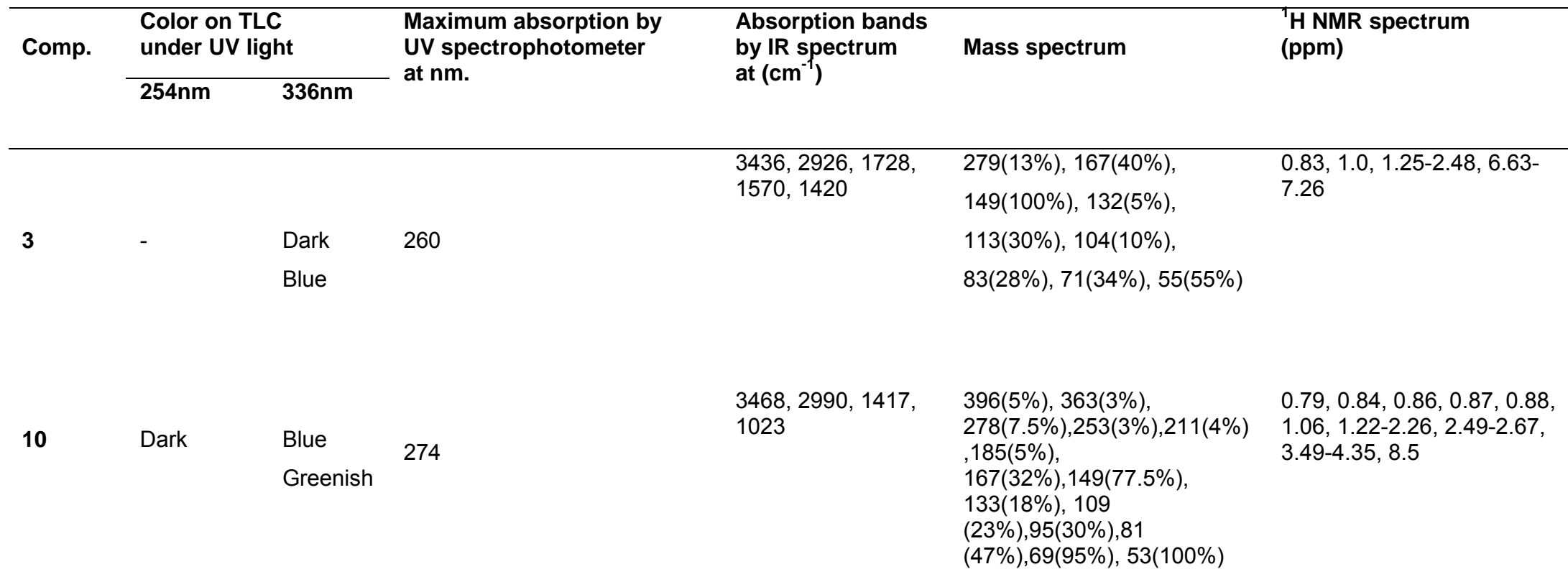




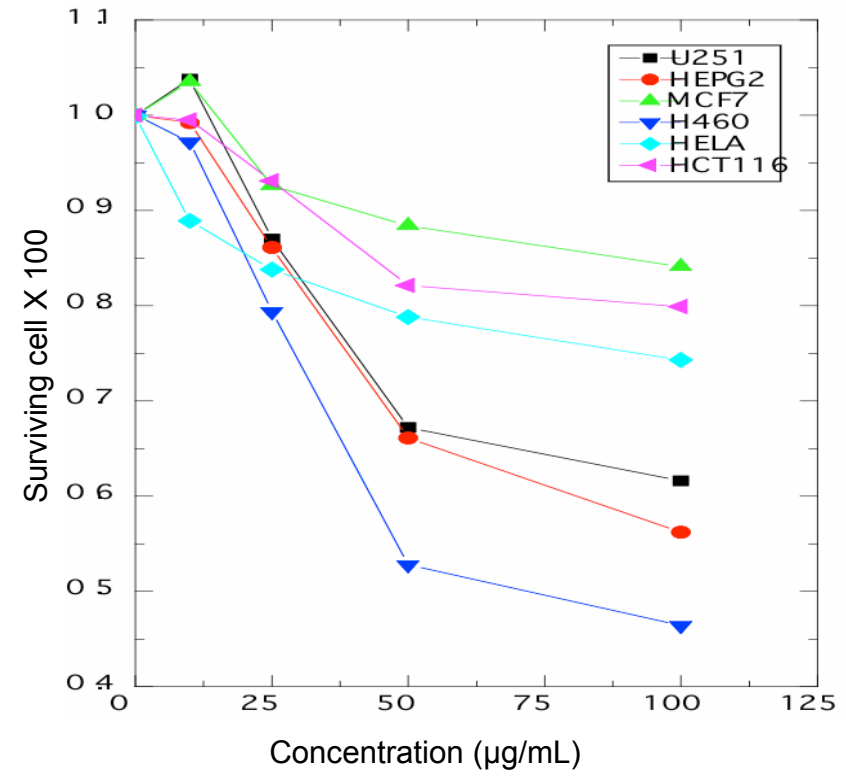

Figure 8: Effect of different concentrations of compound 10 on the viability of 6 different types of tumor cell lines

\section{CONCLUSIONS}

It can be concluded that, isolated marine fungus $V$. ramulosa showed different activities for production of compounds 3 and 10 when grown on malt extract broth medium (MS) at $\mathrm{pH} 6$ on a rotary shaker at 65 r.p.m for 810 days at $24-26{ }^{\circ} \mathrm{C}$ respectively. Compound 3 was identified as dibutyl phthalate, while compound 10 was ergosterol or one of its isomers. The two compounds were evaluated as anticancer compounds. The results proved that compound 10 was a new anticancer compound especially against liver and lung tumor cell lines at concentration $99.7 \mathrm{ug} / \mathrm{mL}$ and $74.9 \mathrm{ug} / \mathrm{mL}$, respectively.

\section{REFERENCES}

Abdel-Wahab, M.A., Asolkar, R.N., Inderbitzin, P. and Fenical, W. (2007) Secondary metabolite chemistry of the marine-derived fungus Massarina sp., strain CNT016. Phytochemistry 68: 1212-1218.

Belofsky, G.N., Jensen, P.R., Renner, M.K. and Fenical, W. (1998) New cytotoxic sesquiterpenoid nitrobenzoyl esters from a marine isolate of the fungus Aspergillus versicolor. Tetrahedron 54:1715-1724.

Belofsky, G.N., Jensen, P.R. and Fenical, W. (1999) Sansalvamide: A new cytotoxic cyclic depsipeptide produced by a marine fungus of the genus Fusarium. Tetrahedron Letters 40: 2913-2916.
Belofsky, G.N., Anguera, M., Jensen, P.R., Fenical, W. and Köck, M. (2000) Oxepinamides A-C and Fumiquinazolines $\mathrm{H}-\mathrm{I}$ : Bioactive metabolites from a marine isolate of a fungus of the genus Acremonium. Chemical European Journal 6(8): 1355-1360.

Bringmann, G., Lang, G., Steffens, S., Günther, E. and Schaumann, K. (2003) Evariquinone, isomericellin, and stromemycin from a sponge derived strain of the fungus Emericella variecolor. Phytochemistry 63: 437443.

Budzikiewicz, H., Djerassi, C. and Williams, D.H. (1964) Structure Elucidation of Natural Products by Mass Spectroscopy. Vol.11, publisher, HOLDEN-DAY, Inc, London.

Chinworrungsee, M., Kittakoop, P., Isaka, M., Rungrod, A., Tanticharoen, M. and Thebtaranonth, Y. (2001). Antimalarial halorosellinic acid from the marine fungus Halrosellinia oceanica. Bioorganic \& Medicinal Chemistry Letters, 11, 1965-1969.

Cueto, M., Jensen, P.R. and Fenical, W. (2000). NMethylsansalvamide, a cytotoxic cyclic depsipeptide from a marine fungus of the genus Fusarium. Phytochemistry 55: 223-226.

Cuomo, V., Palomba, I., Perretti, A., Guerriero, A., D'Ambrosio, M. and Pietra, F. (1995). Antimicrobial activities from marine fungi. Journal of Marine Biotechnology., 2, 199-204.

Ely, R., Supriya, T. and Naik, C.G. (2004). Antimicrobial activity of marine organisms collected off the coast of South East India. Journal of Experimental Marine Biology and Ecologe 304: 121-127.

Farooq Biabani, M.A. and Laatsch, H. (1998). Advances in chemical studies on low-molecular weight metabolites of marine fungi, Journal of Prak. Chem.Ztg., 340, 589-607.

Gu, W., Cueto, M., Jensen, P.R., Fenical, W. and Silverman, R.P. (2007). Microsporins A and B: new histone deacetylase inhibitors from the marine-derived fungus Microsporum gypseum and the solid-phase synthesis of microsporin A. Tetrahedron 63: 65356541.

Höller, U. (1999). Isolation,biological activity and secondary metabolite investigations of marine-derived fungi and selected host sponges. Ph.D.thesis, Von der Gemeinsamen Naturwissenschaftlichen Fakultät der Technischen Universität Carola-Wilhelmina zu Braunschweig.

Iwamoto,C., Yamada,T., Ito,Y., Minoura,K. and Numata, A. (2001). Cytotoxic cytochalasans from a Penicillium species separated from a marine alga. Tetrahedron 57 : 2997-3004.

Jadulco, R., Proksch, P., Wray, V., Sudarsono, Berg, A. and Grafe, U. (2001). New macrolides and furan carboxylic acid derivative from the sponge-derived 
fungus Cladosporium herbarum. Journal of Natural Products 64: 527-530.

Jensen, P. R. and Fenical, W. (2000). Marine microorganisms and drug discovery: current status and future potential. In: Fusetani, N. (Ed.), Drugs from the Sea. Karger, Basel, pp. 6-29.

Keerthi, T.R., Suresh, P.V., Sabu, A., Rajeevkumar, S. and Chandrasekaran, M. (1999). Extracellular production of L-glutaminase by alkalophilic Beauveria bassiana BTMF $\mathrm{S} 10$ isolated from marine sediment. World Journal of microbiology and Biotechnology 15: 751-752.

Kuznetsova, T.A., Afiyatullov, S.A., Denisenko, V.A., Pivkin, M.V. and Elyakov, G.B. (1998). Sterols from a marine isolate of the fungus Cladosporium sphaerospermum Penz. Biochemical Systematics and Ecology 26: 365-366.

Kuznetsova, T.A., Smetanina, O.F., Afiyatullov, S.Sh., Pivkin, M.V., Denisenko, V.A. and Elyakov, G.B. (2001). The identification of fusidic acid, a steroidal antibiotic from marine isolate of the fungus Stilbella aciculosa. Biochemical Systematics and Ecology 29: 873-874.

Liberra, K. and Lindequist, U. (1995). Marine fungi- a prolific resource of biologically active natural products? Pharmazie 50(H9): 583-588.

Lin, Y., Shao, Z., Jiang, G., Zhou, S., Cai, J., Vrijmoed, L.L.P. and Jones, E.B.G. (2000). Penicillazine, a unique quinolone derivative with $4 \mathrm{H}-5,6$-Dihydro-1,2oxazine ring system from the marine fungus Penicillium sp. (strain \#386) from the South China Sea. Tetrahedron 56: 9607-9609.

Lin, X., Huang, Y., Fang, M., Wang, J., Zheng, Z. and Su, W. (2005). Cytotoxic and antimicrobial metabolites from marine lignicolous fungi, Diaporthe sp. FEMS Microbiology Letters: 1-6.

McDonald, L.A., Abbanat, D.R., Barbieri, L.R., Bernan,V.S., Discafani, C.M., Greenstein, M., Janota, K., Korshalla, J.D., Lassota, P., Tischler, M. and Carter, G.T.(1999). Spiroxins, DNA cleaving antitumor antibiotics from a marine-derived fungus. Tetrahedron Letters 40: 2489-2492.

Namikoshi, M. , Akano, K., Kobayashi, H., Koike,Y., Kitazawa, A., Rondonuwu, A. B. and Pratasik, S. B. (2002). Distribution of marine filamentous fungi associated with marine sponges in coral reefs of Palau and Bunaken Island, Indonesia. Journal of Tokyo University of Fisheries 88: 15-20.

Petit, K.E., Mondeguer, F., Roquebert, M.F., Biard, J.F. and Pouchus, Y.F. (2004). Detection of griseofulvin in a marine strain of Penicillium waksmanii by ion trab mass spectrometry. Journal of Microbiological Methods 58: 59-65.

Raghukumar, C., D'souza, T.M.,Thorn, R.G. and Reddy, C.A. (1999). Lignin-modifying Enzymes of Flavodon flavus, a Basidiomycete isolated from a costal marine environment. Applied and Environmental Microbiology 65(5): 2103-2111.

Sabu, A., Keerthi, T.R., Kumar, S.R. and Chandrasekaran, M. (2000). L-Glutaminase production by marine Beauveria sp. under solid state fermentation. Process Biochemistry 35: 705-710.

Sheng Wang, G.Y., Abrell L.M., Avelar, A., Borgeson, B.M. and Crews, P. (1998). New Hirsutane based sesquiterpenes from salt water cultures of a marine sponge-derived fungus and the terrestrial fungus Coriolus consors. Tetrahedron 54: 7335-7342.

Shigemori, H., Komastu, K., Mikamai, Y. and Kobayashi, J. (1999). Seragakinone A, a new pentacyclic metabolite from a marine-derived fungus. Tetrahedron 55: 14925-14930.

Skehan P.and Storeng R. (1990). New coloremetric cytotoxicity assay for anti-cancer drug screening. Journal of National Cancer Institute 82: 1107-1117.

Sun, Y., Tian, L., Huang, Y.F., Sha, Y. and Pei, Y.H. (2006). A new cyclotetrapeptide from marine fungus Trichoderma reesei. Pharmazie 61(9): 809-810.

Suresh, P.V. and Chandrasekaran, M. (1999). Impact of process parameters on chitinase production by an alkalophilic marine Beauveria bassiana in solid state fermentation. Process Biochemistry 34: 257-267.

Tsukamoto, S., Hirota, H., Imachi, M., Fujimuro, M., Onuki, H., Ohta, T. and Yokosawa, H. (2005). Himeic acid $A$ : a new ubiquitin-activating enzyme inhibitor isolated from a marine-derived fungus, Aspergillus sp. Bioorganic and Medicinal chemistry Letters 15: 191194.

Tsukamoto, S., Yoshida, T., Hosono, H., Ohta, T. and Yokosawa, H. (2006). Hexylitaconic acid: a new inhibitor of p53-HDM2 interaction isolated from a marine-derived fungus, Arthrinium sp. Bioorganic and Medicinal chemistry Letters 16: 69-71.

Wei, Hong., Itoh, T., Kinoshita, M., Nakai, Y., Kurotaki, M. and Kobayashi, M. (2004). Cytotoxic sesterterpenes, 6-epi-ophiobolin $G$ and 6-epiophiobolin N, from marine derived fungus Emericella variecolor GF10. Tetrahedron 60: 6015-6019.

Wei, Hong., Itoh, T., Kinoshita, M., Kotoku, N., Aoki, S. and Kobayashi, M. (2005). Shimalactone A, a novel polyketide, from marine-derived fungus Emericella variecolor GF10. Tetrahedron 61: 8054-8058.

Williams, D.H. and Fleming, I. (1980). Spectroscopic Method in Organic Chemistry, $3^{\text {rd }}$ Ed. MCG raw-Hill Book Company (UK) Limited.

Xu, J., Takasaki, A., Kobayashi, H., Oda, T., Yamada, J., Mangindaan, R.E., Ukai, K., Nagai, H. and Namikoshi, M. (2006). Four new macrocyclic trichothecenes from two strains of marine-derived fungi of the genus Myrothecium. Journal of Antibiotics (Tokyo) 59(8): 451-455. 